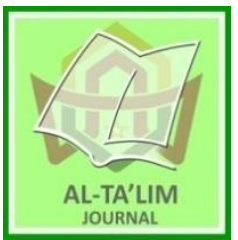

AL-TA'LIM JOURNAL, 28 (2), 2021, (134-144)

(Print ISSN 1410-7546 Online ISSN 2355-7893)

Available online at http://journal.tarbiyahiainib.ac.id/index.php/attalim

\title{
Classroom Assessment for EFL Learning to Speak at Junior high School
}

Received: $27^{\text {th }}$ May 2021; Revised: 02 ${ }^{\text {nd }}$ June 2021; Accepted: $31^{\text {th }}$ July 2021

Permalink/DOI: http://dx.doi.org/10.15548/jt.v28i2.702

\section{Luli Sari Yustina *)}

Universitas Islam Negeri (UIN) Imam Bonjol Padang. Sumatera Barat, Indonesia. E-mail: lulisariyustina@uinib.ac.id

\section{Besral}

Universitas Islam Negeri (UIN) Imam Bonjol Padang. Sumatera Barat, Indonesia. E-mail: besral@uinib.ac.id

\section{Hasnawati}

Universitas Islam Negeri (UIN) Imam Bonjol Padang. Sumatera Barat, Indonesia.

E-mail: hasnawatimpd@uinib.ac.id

\section{*) Corresponding Author}

\begin{abstract}
The present study investigated the current practice of EFL Classroom assessment focusing on speaking skills in Junior High School. Speaking Assessment is a tool used to evaluate students' oral skills in the formal system by the English teachers. The investigation of classroom speaking assessment in this school was based on its effectiveness in light of alternative assessment tool and pedagogical values. By using ADDIE model, we constructed an oral assessment in accordance with the needs and levels of students as well as components on the oral assessment. There were five commons models such as Oral Interview, Role Play, Guessing Games, Story Telling and Oral Report that are communicative, relevant, continues, simple and various forms. These models can be used to assess students' speaking skills regardless of time and place as its validity and practicality tests appeared to be high (93.75 and 87.5). It can be concluded that these assessment models are applicable for teachers to assess students' speaking skill. The paper further elaborates discussion on the utilizing of students' ability, progress, and their learning process. In short, it is a high time for the teachers to apply these models in the classroom.
\end{abstract}

Keywords: English Language Teaching (ELT); lessons plan; speaking.

How to Cite: Yustina, L., Besral, B., \& Hasnawati, H. (2021). Classroom Assessment for EFL Learning to Speak at Junior high School. Al-Ta lim Journal, 28(2). doi:https://doi.org/10.15548/jt.v28i2.702

\section{INTRODUCTION}

Assessment is an ongoing process that encompasses a wide range of methodological techniques. Whenever a student responds to a question, offers a comment, or tries out a new word or structure, the teacher subconsciously makes an appraisal of the student's performance (Boud, 2000; Buzzetto-More \& Alade, 2006). It is one of the important components in learning process. It describes not only the result of the students' final result but also the process that has been allowed by the students to achieve the result (DarlingHammond et al., 2012; Kubiszyn \& Borich,
2016; Papay, 2012). Assessment has been discussed by different expert in different ways. (Douglas \& Frazier, 2001) showed the interrelationship among the testing, measurement, assessment, teaching and evaluation. It shows then that all tests are formal assessment but not all formal assessment is testing.

The criteria of this assessment include attitude, motivation, and performance of the students. This kind of assessment is relevant with communicative language teaching which emphasizes students to do much practice (Sugano \& Mamolo, 2021; Zilberberg et al., 
2014). In assessing English subject especially at junior high school, the students are expected to achieve competence that enables them to communicate functionally and meaningfully. Based on curriculum 2013, English subject are taught in communicative way where the students are the center of the activities. Related to the activities, the students have many opportunities to practice their speaking and teacher can assess students intensively through communicative activities in the classroom. There are many ways to assess students authentically, for instance role play, oral interview, storytelling, and information gap. The speaking subject is thought to be integrated with other skills while in assessing students' speaking activities the teacher had to use some kinds of authentic assessments such as role play, presentation and small group discussion (Kayi, 2006; Richards, 2006; Syafryadin et al., 2020; Yalçın \& İnceçay, 2014). However, based on the result of interview with one of the teachers at State Junior High School 1 Padang, that in assessing students speaking skill, the teacher used the rubric that classified the students' ability into 'good, very good and excellent'. There is no certain rubric to assess students' speaking activities since the rubric is only created by the teacher herself without concern to the authentic activities.

Students' EFL speaking at State Junior High School 1 Padang is known to be already confident in practice. However, the teacher did not have serious problem in applying authentic activities in the classroom. It seemed that the teacher did not provide the appropriate rubric to assess the authentic activities in order to achieve better description of the students in speaking activities. Teachers ideally assess students' speaking skill in separated time with other skill since each skill certainly has distinct component or criteria (Akbari, 2015; Mustafa et al., 2017). To create an enjoyment activity in speaking class, authentic activities need to be applied even assessment in speaking such as: oral interview, information gap, storytelling and other type of assessments. Moreover, teacher should state specific criteria and the appropriate rubric to assess students' speaking skills.
Related to the importance of assessment in teaching and learning process, every subject should be assessed appropriately to gather information about students' progress and achievement. However, assessment that is applied by teacher cannot completely measure students' ability. According to Syahidah \& Umasugi, 2021, speaking is a productive skill that can be directly and empirically observed, those observations are invariable collared by the accuracy and effectiveness of a test-takers' listening skill, which necessary compromises the reliability and validity of an oral production test. Speaking is one of the four language skills that plays an important role in daily communication. By speaking, people can express their own ideas and helps them to inform something what they think to the others. It is an interactive process of constructing meaning that involves producing and receiving and processing information (Hidayati, 2018; Inbar-Lourie, 2008).

Richards (2006) defines speaking as 'negotiation of the meaning' that has to be considered by someone's utterance. It means 'anticipating the listeners' response and possible misunderstandings, clarifying one's own and other's intentions, and arriving at the closest possible match between intended, perceived, and anticipated meanings". Speaking in a classroom entail interacting with the teacher and peers, depending on how classroom activities are organizes.

Speaking is an 'oral productive skill which happens face to face between speaker and hearer' (Widdowson, 2015). It is an interactive process to 'build meaning which covers producing, receiving, and processing information' (Burns, 2008; Burns \& Seidlhofer, 2013). Speaking is one of the four skills that students should master in learning English as a compulsory subject in all levels of education. Many students regard speaking skill measurement of knowing a language. They define fluency as the ability to speak with others. By learning speaking, the students know the way to express opinions, emotions, feelings and ideas meaningfully.

Nunan (2018) says that speaking is the 'oral skill that consists of producing systematic 
verbal utterance to convey meaning'. In Speaking, there are three functions of speaking namely function as interaction, transaction, and performance (Richards, 2008). Function as interaction refers to 'daily conversation in daily life environment'. The main aims of conversation are to 'build social relationship and to create satisfying interaction with other people' (Richards \& Rodgers, 2001).

In language teaching, the ability to speak can be indicated by mastering pronunciation, grammar, vocabulary, fluency and comprehension. In order to make students able to speak English, the teaching of speaking must cover those components. The ability to speak can be developed through some activities in learning process. Those activities are dialogues, plays, free discussions, roleplay, story-telling, interviews, reporting, playing cards, picture narrating and describing and also find the difference.

Assessment is a way to seek and to get the answer about what students should know, what the institution contributes to student growth, how learning can be improved. Assessments should include input and environment (i,e. where students start from), as well as students' experiences through the process of schooling and educational outputs. Assessment is a tool to measure students learning or program progress as it becomes a very powerful as a consideration should be taken into account to build a fair and valid assessment. It is often considered as an 'important instructional step'. The way learners are taught and carried out the activities at classroom are greatly influenced by assessment. Fulcher \& Reiter (2003) mentioned 'the success of the learning program is commonly determined by the result of assessment'.

The assessment is the "process to obtain the information in any form that can be used to make decision for students with the curriculum, learning programs, school climate, and school policies' (Hoffman et al., 2011; Oliver et al., 2005; Pray, 2005). It is clear that the purposes of the assessment are to: (1) diagnose the strength and weaknesses of students in learning, (2) monitor the progress of students, (3) determine the level of student's ability, (4) determines the effectiveness of learning, (5) affect public perception about the effectiveness of learning. According to Brown (2004), there are two majors important elements in assessing speaking such as 'accuracy and fluency'. Accuracy refers to vocabulary, grammar, pronunciation, stress, and intonation. Meanwhile, fluency refers to the meaning and the spontaneous of language use. It could be noted that, teachers assess students speaking skill by considering fluency and accuracy. Parallel to this idea, Harris (2005) affirms five components in assessing speaking skill namely pronunciation, structure, vocabulary, fluency and content. All those concepts must be prioritized by teachers when assessing speaking.

Oral language assessment in school aims to capture students' ability to communicate both basic communicative and academic purposes. Sukma et al. (2019) alleges the basic communicative is a conversation/talk that can be done face to face where meaning can be negotiated by considering facial expression, gesture, paralinguistic and tone. In contrast, academic purposes ask students to speak formally in order to get success in academic. Academic language is found in the content areas where students asked to use language formally. As stated earlier, there are a number of activities that include in speaking authentic assessment: (1) Oral interview, (2) Pictured cued description or stories, (3) Radio broadcast, (4) Video clips, (5) Information gaps, (6) Story / Text Retelling, (7) Role play / simulation / improvisation, (8) Debates, (9) Presentation, (10) Drama/Play (11) Free discussions, (12) Interviews, (13) Reporting, (14) Playing cards, and (15) Picture narrating and describing.

\section{Scoring Rubric for Speaking}

Scoring rubric is essentially important point to be considered when assessing speaking. Scoring rubric is an established set of criteria for scoring or rating students' performance, in this case for scoring students' speaking. Speaking scoring rubric consists of some criteria for assigning a score or rating on students' speaking performance. Barootchi \& 
Keshavarz (2002) present the scoring rubric for speaking both analytical and holistic as follows:

Table. 1. Analytical Speaking Scoring Rubric

\begin{tabular}{clc}
\hline Aspects & \multicolumn{1}{c}{ Criteria } & Scoring \\
\hline \multirow{5}{*}{ Speaking } & 1 \\
& Begins to name concrete object & 2 \\
& Begins to communicate personal and survival needs & 3 \\
& Begins to initiate conversation: retell a story or experience; asks and responds to & \\
& simple question & \\
& Initiates and sustains a conversation with descriptors and details; exhibits self- & 4 \\
& confidence in social situation; begins to communicate in classroom setting & \\
& Speak in social and classroom setting with sustained and connected discourse; any & 5 \\
& errors do not interfere with meaning & \\
& Communicate competently in social and classroom setting & 6 \\
& Repeats words and phrases & 1 \\
Speaks in single words utterances and short patterns & 2 \\
Speaks hesitantly because of rephrasing and searching the words & 3 \\
Speak with occasional hesitation & 4 \\
Speak with near native fluency; hesitation do not interfere with communication & 5 \\
Speak fluently & 6 \\
Uses predominantly present tense verb; demonstrate error of omission (leaves & 3 \\
word out, word ending off) & 4 \\
Uses some complex sentences; applies rules of grammar but lack control of & \\
irregular forms & 5 \\
Uses of variety of structures with occasional grammatical errors & 6 \\
Masters a variety of grammatical structure & 2 \\
Uses functional vocabulary & 3 \\
Uses limited vocabulary & 4 \\
Uses adequate vocabulary; some words uses irregularities & 5 \\
Uses varied vocabulary & 6 \\
Uses extensive vocabulary but may lag behind native speaking peers & 1 \\
Understanding little or no English & 2 \\
Understands words and phrases, requires repetition & 3 \\
Understands simple sentences in sustained conversation; requires repetition & 4 \\
Understanding classroom discussion with repetition, rephrasing and clarification & 5 \\
Understands most spoken languages, including classroom interaction & 6 \\
\hline Understands classroom discussion without difficulty & \\
\hline
\end{tabular}

It could be figured that analytical scoring rubric accommodates teachers to assess students speaking by stating several specific aspects. Analytical rubric scoring has several criteria namely: speaking, fluency, structure, vocabulary and listening. That is to say, this type of rubrics can be used if the teachers want to see the strength and weakness on students' performance and assess complicated skill or performance. Teachers score the students by considering criteria in the rubrics.

Table. 2. Holistic Speaking Scoring Rubric

\begin{tabular}{ccl}
\hline Rating & & \multicolumn{1}{c}{ Description } \\
\hline & - & Communicates competently in social and classroom settings \\
& - & Speaks fluently \\
6 & - & Masters a variety of grammar structures \\
& - & Uses extensive vocabulary but may lag behind native speaker peers \\
& - & Understands classroom discussion without difficulty \\
& - & Speaks in social and classroom setting with sustained and connected discourse; any errors do \\
& & not interfere with meaning \\
& - & Speaks with near-native fluency; any hesitation do not interfere with communication \\
5 & - & Uses varied vocabulary \\
& - & Understands simple sentences in sustained conversation; requires repetition \\
\hline
\end{tabular}




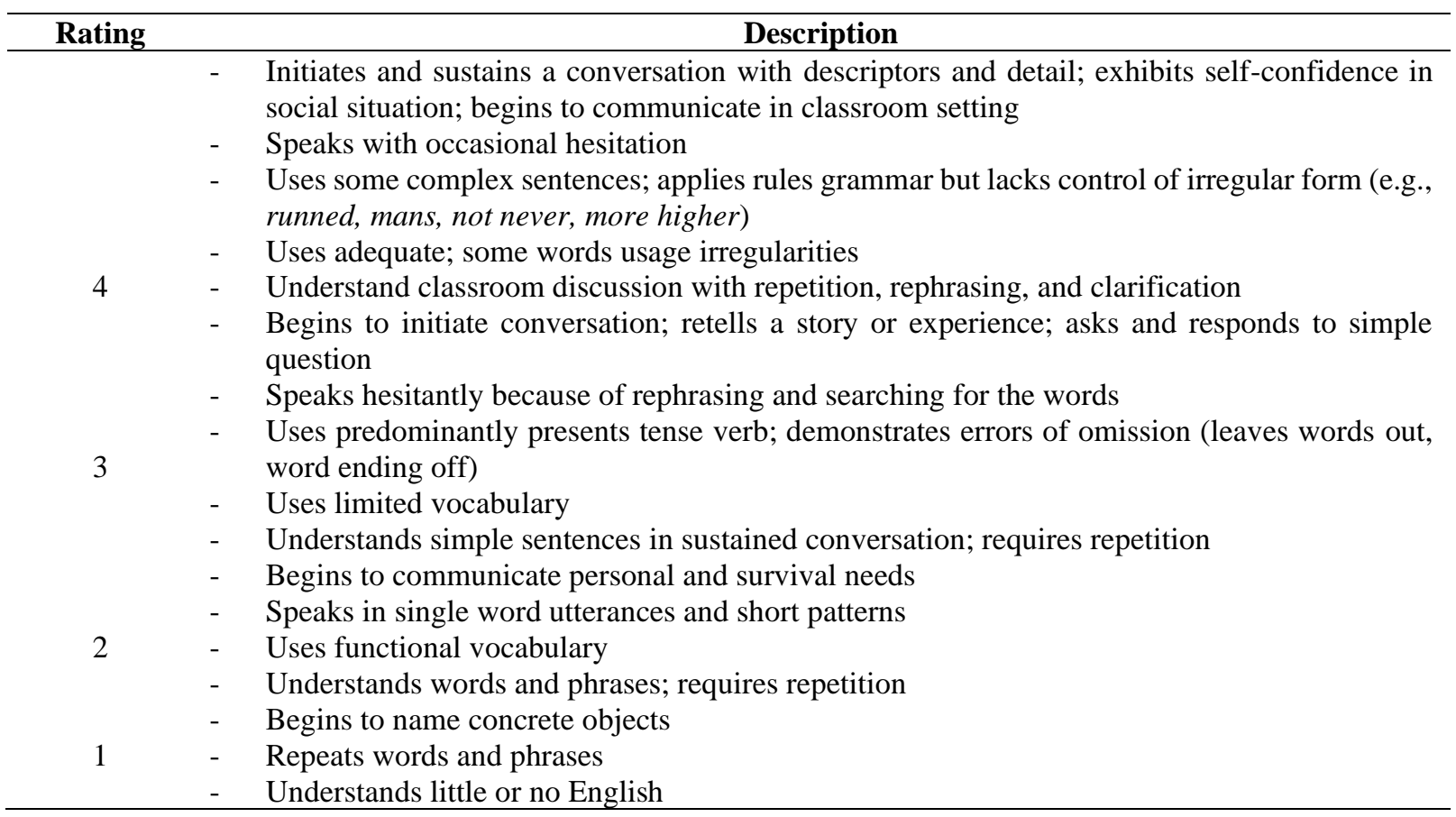

On the other hand, holistic scoring rubric tells students' rating speaking ability. It states scale from lowest one into the highest one. The lowest score would be scored 1 , while the highest one would be scored by 6 . Rating 1 means students are in lowest level where they only begin to name concrete objects and repeat some words and phrases. Meanwhile, students in level 6 are in advanced learner who can speak fluently.

\section{METHOD}

The type of this research is research and development since this research aims to develop assessment for speaking skill for grade nine at State JHS 1 Padang. This research used ADDIE model which is developed by Branch (2009) that stand for analyze, design, develop, implement, and evaluation. ADDIE is an instructional model how to develop new product. The procedure of ADDIE can be described into five phases, analyzing the need analysis both present and target condition, designing the appropriate product, developing the new product by asking the expert, implementing the new product and getting the feasibility of new product from the teachers.

ADDIE, (acronym for Analyze, Design, Develop, Implement, and Evaluate) approach of Instructional design (Branch, 2009) was used in the study through the following phases: In the analyze phase, the instructional problem is clarified, the instructional goals and objectives are established and the learning environment and learner's existing knowledge and skills are identified. In this phase, researcher analyzed need analysis toward present condition. After getting information from need analysis, researchers come to design the product. The design phase should be systematic and specific. Researcher tries to design new product that match and meet with students' needs.

The development phase is where instructional designers and developers create and assemble the content assets that were blueprinted in the design phase. Blue print of design steps would be developed into real action by the researcher. During the implementation phase, a procedure for training the facilitators and the learners is developed. The facilitators' training should cover the course curriculum, learning outcomes, method of delivery, and testing procedures. The evaluation phase consists of two parts: formative and summative. Formative evaluation is present in each stage of the ADDIE process. Summative evaluation consists of tests designed for domain specific criterion-related referenced items and providing opportunities for feedback from the users which were identified 


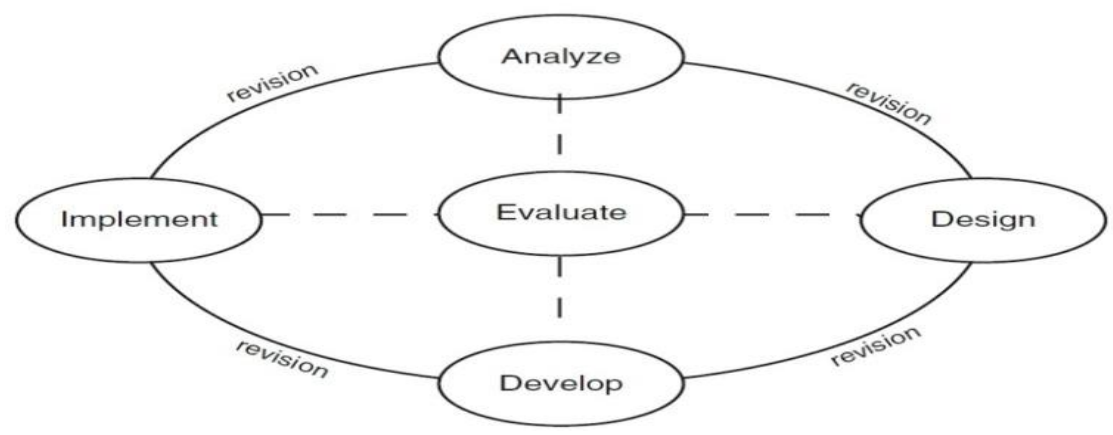

Figure 1. ADDIE Model

Source: Branch (2009)

ADDIE model is suitable for researching language and education field. So that is why researcher has chosen this type of design model being the appropriate model. There are many types of instructional design processes that can be used, but ADDIE ranks high in the order of instructional effectiveness. The flexibility of the ADDIE model invites evaluation at each step, but also encourages evaluation, redesign, and adaptations at every turn if the designer wants to keep to a process that reacts well to change. One reason for the widespread use of the ADDIE model is that it is extremely valuable for large and complex teaching designs.

\section{Research Procedure}

There are five phases conducted in this research. It is started by analyzing the need analysis on assessment for speaking skill and ended by evaluating the new model through perception of the users. Completely, those phases are presented as follows:

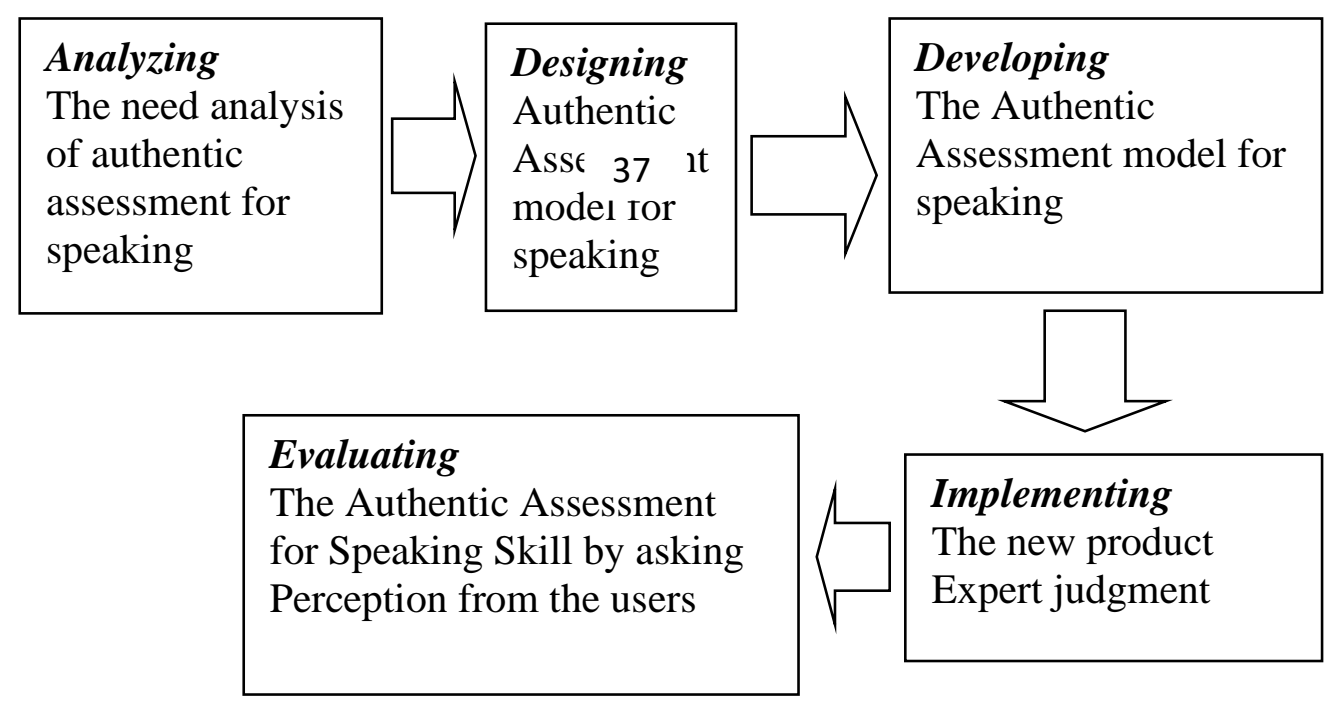

Figure. 2. Flowchart of Research Procedure

Analyze: This stage analyzes students and teachers' needs that include students' wants, lack, and necessity in speaking skill. Commonly, the purpose of teaching English at junior high school is to develop students' competence of oral communication at the functional level. The result of the analysis will be counted in choosing the appropriate types of speaking assessment.
Design: Designing appropriate assessment for speaking skill at grade nine matched with needs analysis and standard and basic competency for speaking skill for grade nine. In this phase, researcher also investigated current model of assessment that has been applied by the teacher. Researcher paid more attention on what were the advantages and disadvantages of previous models. 
Develop: In this phase, researcher developed model of assessment that appropriately matched and met with students' need. The model of assessment for speaking is validated by the experts in order to get validation. On this case, researcher needed judgment from validators who were experts on assessment especially speaking skill. After getting judgment from the experts, researcher revised the model in order to get better result of speaking assessment.

Implementation: In this phase, researcher implemented the authentic assessment models to the students at grade nine at State Junior High School 1 Padang. The product is implemented twice to the students. By implementing the product, researcher checked students' perception toward the product. Besides, by implementing the models of assessment researcher checked the practicality of the products.

Evaluation: In the fifth steps, the writer evaluated assessment that has been developed and implemented. This process had been done by checking practicality of the product. After that, the writer asked the teacher to give opinion and suggestion about speaking assessment that has been implemented. The purpose of this evaluation is to see the practicality of speaking assessment.

\section{RESULT AND DISCUSSION}

The research findings were categorized into five items including need analysis of the students' and teachers' needs, design appropriate speaking assessment, developing a model of authentic assessment, implementation of model and evaluation of the authentic assessment speaking skill.

\section{Reason to Assess Students' Speaking}

Dealing with the questionnaire result, there were three indicators and four statements of the reasons to assess the students speaking. There are three sub-indicators reasons to assess students' speaking. The first, the necessity belongs to speaking assessment is done by the teacher to know the speaking skill $88.55 \%$, it is high. Visible or not belong to speaking assessment that had been done by teacher did not encourage students' speaking skill 75.6, this category is high. Then, Students' and teachers' attitude toward speaking assessment has two statements, namely: speaking assessment was done by the teacher to know students' speaking score $85.24 \%$, it is a high category. The last, speaking assessment as feedback $80.72 \%$, the category is high. So, based on the percentages, the highest score is speaking assessment was done by teacher to know my (students) speaking score $85,72 \%$. All of the reasons are belonged to high category.

\section{Way to Assess the Learners}

There were two items dealing with the ways to assess the learners. Each of subindicators has items each other, all of the statements are for the students (item $5=67.78 \%$ ), the category is middle. Then, speaking assessment for their friends cannot help students' speaking $(6=70.48 \%)$, the category is middle. Next, speaking assessment has to measure students' speaking skill (item $23=87.88 \%$ ), the category is high.

Furthermore, Methodology to assess students' speaking has five items. They are speaking assessment must be simple (7$88.55 \%$ ). the category is high. Moreover, speaking assessment must have variation (item $8=46.68 \%$ ), the category is low. Then, speaking assessment model must be communicative $(9=88.86 \%)$, it is high category. Next, the speaking assessment must have the clear indicator $(10=89.16 \%)$, it is belonged to high category. The last is speaking assessment must be fun $(32=97.28 \%)$. It can be concluded that there is one item belonging to low category, two belonging to middle category, and five belonging to high category, but the highest belonging to item 32 , the speaking assessment must be fun (97.28\%).

\section{Available Source}

There were four sub-indicators in available source based on the students need, namely: teachers' concept of assessment, material, media and environment. The 
available source there are ten items namely speaking assessment must be done by professional teacher (item $19=86.75$ ), it is belong to high category. Then, speaking assessment must-have rubric (item $21=$ $78.61 \%$ ), the category is high. Next, speaking assessment must-have component (item $22=$ $88.82 \%$ ), it is high category. Furthermore, speaking assessment must consist of material (item $20=79.21 \%$ ), that belong to high category. Then, speaking assessment must consist to all of the material (item $25=$ $87.35 \%$ ), that is belong to high category.

Moreover, speaking assessment must have appropriate media (item $27=74.1 \%$ ), that is belong to high category. Speaking assessment must have many pictures (item 34 $=72.89 \%$ ), that is belong to high category. Speaking assessment must use sound and CD (item $35=83.13 \%$ ), that is belong to high category. Speaking assessment must use sound and picture (item $36=78.91 \%$ ), that is belong to middle category. The last item, speaking assessment applied in comfortable situation and condition (item $39=90.6 \%$ ), that is belong to high category. So, it can be concluded that the highest is belong to environment $(90.06 \%)$.

There were five models of authentic assessment proposed by researcher namely: role play, picture-cued description, oral report, story/text retelling, and guessing games. All of them were considered suitable and appropriate to be applied in assessing speaking. Besides, they were communicative, authentic, simple and relevant to the students. Moreover, each of model has own scoring rubric. Scoring rubric narrated same criteria especially on the way how to give score.

In the research question is about students' needs for speaking at grade IX Junior High School. To answer this research question, researcher gave questionnaire to the students. Students need assessment when the teachers assess their speaking skill. There are several important points of students' needs to assessments for speaking. A primary concept to be considered by researcher is need analysis, due to need analysis plays important issues before designing an assessment model. Noaman et al., (2017) claims that need analysis should be a starting point for devising syllabuses, courses, material and others kind of teaching and learning that take place. In accordance with questionnaire, there are several students' needs to be considered before designing the assessment model for speaking. Students well accepted that speaking is an important skill that must be learnt by them. Doing so, they completely agreed assessment for speaking must be conducted by teachers. Assessing speaking is a way for students to know their achievement, ability and progress. Then, students need assessment model that relates with their daily life.

Students had chosen speaking assessment by several conditions. This facilitated students to be an active learner during teaching learning process. The assessment has multiple forms, not merely one form. It gave much opportunity for students to practice their skill and ability in several ways. If they have weakness in one model, the others can cover it. Then, since assessment has scoring rubric. Scoring rubric explains detail criteria that would be obtained in an assessment Teachers also got ease in scoring their students' performance, since scoring rubric stated clear and concise narration.

Students prefer communicative assessment model that can facilitate student to speak interactively and contextually. Contextual is the main key on this model in order to support students speak in real context. Students wanted various model not only rely on one model to be conducted There is no single model on assessing speaking, since assessment basically facilitates various models. By having various model, students got broaden chance to develop their ability. Moreover, students mostly wanted communicative assessment model. Communicative activity means student got much chance to speak, to elaborate, to interact their idea and opinion one to another student. Teachers only as facilitators who facilitates students to explore their creativity over and over. In line with communicative activity, Zigarovich \& Myers (2011) offer the following four characteristics of a communicative view of language: 1) Language is a system for the expression of meaning; 2) The primary 
function of language is for interaction and communication; 3) The structure of language reflects its functional and communicative uses; 4) The primary units of language are not merely its grammatical and structural features, but categories of functional and communicative meaning as exemplified in discourse.

Role play is valuable activity to promote speaking skill. It gives students an opportunity to practice communicating in different social and roles context. Role play encourages students to express their ideas and feelings in a relaxed environment condition. It is a kind of communicative techniques which develops fluency in promoting interaction in the classroom and increasing motivation. Role play develops students' self-confidence when they speak up one to another. An oral report is a presentation, usually done for a student to teachers and classmates, though it can also be done for a larger segment of the school community, for parents, or for a more open group, depending on the circumstances.

An oral report is an opportunity for students to practice their speaking skills, but other skills may come into play as well. There are presentation skills, such as making eye contact with the audience, listening skills of a question-and-answer session, and the skill of anticipating how to present something in a way that will be understandable as well as appealing to the particular audience. Last of all, guessing games has been chosen by teachers and students as an applicable and suitable assessment. Basically, guessing game is the commonest assessment activity for students at lower level such as junior high school. Students try to tell describe people/ animals/ things to their friends, then the other friends try to guess the presenter describe.

Speaking fluently is the aim of many language learners. Signs of fluency include a reasonably fast speed of speaking and only a small number of pauses and hesitation. These signs indicate that the speaker does not have to spend a lot of time searching for the language items needed to express the message. Comprehension also takes important element in speaking. Comprehension deals with communication between speaker and hearer. Good communication happens if both speaker and listener know what they are talking about. Conversely, misunderstanding appears if both speaker and listener cannot catch the meaning of a conversation. It means, a listener must listen carefully to the speaker's utterances before responding to the speaker.

\section{CONCLUSIONS AND RECOMMENDATION}

Students at grade IX Junior High School I Padang need assessment. Most of the students want fair or fun assessment, easy to do, use sound system, $\mathrm{CD}$ and cassette. Besides, the assessment should be able to encourage students to be active learner, and it must be used in the comfortable and funny situation. Students need various assessment models, not merely one model, so they can get more chances to develop their speaking skill.

There were five models that had been developed in this study. Those models had been developed by considering the need analysis of students grade IX SMP Negeri 1 Padang. Those authentic assessment models are as follows: role play, oral interview, oral report, story text retelling and guessing games. The assessment models have been developed by researcher by using ADDIE design model. There are several phases have been conducted by researcher in order to get well developed models. First of all, analyzed students' needs analysis toward authentic assessment. Then, researcher designed the model of authentic assessment that appropriate for the students. Researcher developed the model of authentic assessment. The next step is researcher invited some experts to validate the models. Insight and suggestion from experts have been important information for researcher to do revision. Final the product of the authentic assessments for speaking skill were obtained by researcher after following several revisions.

Those speaking assessments model are practical and applicable model for SMP Negeri especially for grade IX SMP Negeri Padang. Since, those models have been well validated by the most skilled and reliable experts. The assessment models are feasible for the users, 
particularly for the teachers and students. Those authentic assessment models have followed long and procedural steps until they can be applied to the students in order to assess students' speaking skill. The models have been well analyzed by researcher, judged by qualified experts, and checked carefully the practicality by the users. Surely, they are applicable and feasible for assessing speaking at grade IX SMP Negeri 1 Padang.

\section{REFERENCES}

Akbari, Z. (2015). Current challenges in teaching/learning English for EFL learners: The case of junior high school and high school. Procedia-Social and Behavioral Sciences, 199, 394-401.

Barootchi, N., \& Keshavarz, M. H. (2002). Assessment of achievement through portfolios and teacher-made tests. Educational Research, 44(3), 279-288.

Boud, D. (2000). Sustainable assessment: Rethinking assessment for the learning society. Studies in Continuing Education, 22(2), 151-167.

Burns, A. (2008). Teaching speaking: A textbased syllabus approach. In Current trends in the development and teaching of the four language skills (pp. 235260). De Gruyter Mouton.

Burns, A., \& Seidlhofer, B. (2013). Speaking and pronunciation. In An introduction to applied linguistics (pp. 207-224). Routledge.

Buzzetto-More, N. A., \& Alade, A. J. (2006). Best practices in e-assessment. Journal of Information Technology Education: Research, 5(1), 251-269.

Darling-Hammond, L., Amrein-Beardsley, A., Haertel, E., \& Rothstein, J. (2012). Evaluating teacher evaluation. Phi Delta Kappan, 93(6), 8-15.

Douglas, D. A. N., \& Frazier, S. (2001). Teaching by Principles: An Interactive Approach to Language Pedagogy .: H. Douglas Brown. Wiley Online Library.
Fulcher, G., \& Reiter, R. M. (2003). Task difficulty in speaking tests. Language Testing, 20(3), 321-344.

Hidayati, K. H. (2018). Teaching writing to EFL learners: ' ' Ivestigation of challenges confr...... by Indonesian teachers. Langkawi: Journal of The Association for Arabic and English, 4(1), 21-31.

Hoffman, L. M., Loeb, D. F., Brandel, J., \& Gillam, R. B. (2011). Concurrent and construct validity of oral language measures with school-age children with specific language impairment.

Inbar-Lourie, O. (2008). Constructing a language assessment knowledge base: A focus on language assessment courses. Language Testing, 25(3), 385-402.

Kayi, H. (2006). Teaching speaking: Activities to promote speaking in a second language. The Internet TESL Journal, 12(11), 1-6.

Kubiszyn, T., \& Borich, G. D. (2016). Educational testing and measurement. John Wiley \& Sons.

Mustafa, F., Kirana, M., \& Bahri, S. (2017). Errors in EFL writing by junior high students in Indonesia. International Journal of Research Studies in Language Learning, 6(1), 38-52.

Noaman, A. Y., Ragab, A. H. M., Madbouly, A. I., Khedra, A. M., \& Fayoumi, A. G. (2017). Higher education quality assessment model: Towards achieving educational quality standard. Studies in Higher Education, 42(1), 23-46.

Nunan, D. (2018). Teaching speaking to young learners. The TESOL Encyclopedia of English Language Teaching, 1-8.

Oliver, R., Haig, Y., \& Rochecouste, J. (2005). Communicative competence in oral language assessment. Language and Education, 19(3), 212-222.

Papay, J. (2012). Refocusing the debate: 
Assessing the purposes and tools of teacher evaluation. Harvard Educational Review, 82(1), 123-141.

Pray, L. (2005). How well do commonly used language instruments measure English oral-language proficiency? Bilingual Research Journal, 29(2), 387-409.

Richards, J. C. (2006). Developing classroom speaking activities: From theory to practice. Guidelines-SingaporePeriodical For Classroom Language Teachers Then Magazine For Language Teachers-, 28(2), 3.

Richards, J. C., \& Rodgers, T. S. (2001). I Major language trends in twentiethcentury language teaching. Approaches and Methods in Language Teaching (Cambridge Language Teaching ....

Sugano, S. G. C., \& Mamolo, L. A. (2021). The Effects of Teaching Methodologies on Students' Attitude and Motivation: A Meta-Analysis. International Journal of Instruction, 14(3), 827-846.

Sukma, E., Mahyudin, R., Rahmatina, R., \& Suriani, A. (2019). Problems in Oral Language Teaching in Primary School. Seventh International Conference on Languages and Arts (ICLA 2018), 379383.

Syafryadin, S., Martina, F., \& Salniwati, S. (2020). Compensation strategies in speaking activities for non-English department students: Poor and competent speakers. JEES (Journal of English Educators Society), 5(2), 109116.

Syahidah, U., \& Umasugi, F. (2021). A Design Of Speaking Assessment Rubric For English Immersion Camp. Exposure: Jurnal Pendidikan Bahasa Inggris, 10(1), 31-46.

Widdowson, H. (2015). ELF and the pragmatics of language variation. Journal of English as a Lingua Franca, 4(2), 359-372.

Yalçın, Ö., \& İnceçay, V. (2014). Foreign language speaking anxiety: The case of spontaneous speaking activities. Procedia-Social and Behavioral Sciences, 116, 2620-2624.

Zigarovich, K. L., \& Myers, S. A. (2011). The Relationship between Perceived Instructor Communicative Characteristics and College Students' Conflict-handling Styles. Journal of Instructional Psychology, 38(1).

Zilberberg, A., Finney, S. J., Marsh, K. R., \& Anderson, R. D. (2014). The role of students' attitudes and test-taking motivation on the validity of college institutional accountability tests: A path analytic model. International Journal of Testing, 14(4), 360-384. 